\title{
$[5]$
}

\section{From Equal Protection to Suspect Classification}

The promises of Reconstruction were not kept. Perhaps it should not surprise us that the congressional commitment to equality did not endure; at any rate, it lasted barely ten years, if that long. The last major law that passed, badly weakened from its original version, was the Civil Rights Act of I875; and a year later it was all over. The compromise that gave Rutherford Hayes the presidency withdrew federal troops from the South and returned power to white southern Democrats. After that, slowly and inexorably, the whites reestablished their dominance and returned the blacks to subjection, though not to slavery. ${ }^{1}$

The Supreme Court cannot be assigned primary responsibility for this regression. But its interpretations of the Fourteenth Amendment contravened Radical Republican principles as badly as Congress and the states did. The lavish grant of liberty and equality was narrowed into a guarantee of a few rights that were not, in fact, protected; the group that benefited most from the Fourteenth Amendment in its first fifty years consisted of large corporations. ${ }^{2}$ As late as 1935 , one historian noted that

the Supreme Court in construing the "equal protection of the laws" provision of the Fourteenth Amendment has conformed to a degree to the pro-slavery theory of a classified equality instead of to the anti-slavery theory of this essential right of every individual to equality with every

${ }^{1}$ See Kluger, Simple Justice, pp. 61-62; C. Vann Woodward, The Strange Career of Jim Crow, 2d rev. ed. (New York: Oxford University Press, 1966).

${ }^{2}$ The major case here is, of course, Lochner v. New York, 198 U.S. 45 (1905). 


\section{Equality under the Constitution}

individual under the law. The Supreme Court permits the classification of persons within a State for the purpose of legislation whenever a substantial basis for legislation can be found, but the Court, of course, has never accepted the Southern idea that race is such a substantial basis. ${ }^{3}$

In a way, though, it had; Plessy v. Ferguson can be read as a statement of the appropriateness of certain racial classifications for achieving legislative ends, and Plessy was still good law in $1935 .{ }^{4}$ Most readers would now dismiss the quoted statement as no longer true. They would be wrong. In essence, the passage still accurately describes the way in which Fourteenth Amendment cases are decided. There are some new wrinkles since 1935 , but the emphasis is still on classification and discrimination rather than on the essential right of equality.

One increasingly popular school of thought maintains that if the Court initially narrowed the Fourteenth Amendment, since 1954 it has enlarged it beyond recognition. ${ }^{5}$ I argue here that this is not true; that judicial interpretation remains stingy and niggling; and that, in particular, the doctrine of suspect classification has been superimposed on the amendment at considerable cost to individual rights. Yet it cannot be said that the Court has acted with malevolence, or even with bias. It has just acted like a group of lawyers.

The rules as developed over the years were refined in an orderly fashion, from precedent to precedent; they have traceable roots; and, initially at least, they made sense. The trouble is that they start out having little to do with the Fourteenth Amendment, and end up having less and less to do with it. A comparison of these cases with the legislative history brings home the truth of the statement of Graham's which I quoted near the end of Chapter 4. The Reconstruction Congress did not think about constitutional law in the same way that postreconstruction lawyers and judges do. It was judges, alas, that had the task of giving meaning to the Fourteenth Amendment, and the meaning they have given it has changed it drastically.

The first two Fourteenth Amendment cases heard by the Court well illustrate the flexibilities of the text. Despite the fact that the freed slaves had been Congress' paramount concern, neither case had anything to do with them. The Slaughter-House Cases of 1873 were brought by New Orleans butchers threatened by a state-conferred monopoly, while Bradwell v. Illinois, decided the same day, involved a woman

\footnotetext{
${ }^{3}$ William Sumner Jenkins, Pro-Slavery Thought in the Old South (Chapel Hill: University of North Carolina Press, 1935), p. I99n.

${ }^{4}$ I 63 U.S. 537 (1896).

${ }^{5}$ See Berger, Government by Judiciary; Graglia, Disaster by Decree.
} 
who had been denied a license to practice law. ${ }^{6}$ Feminists have given Bradwell some notoriety, but our concern here has to be with SlaughterHouse, which had greater influence on doctrinal development. The butchers, like Myra Bradwell, lost their case, but they lost primarily because of what the Court then saw as the amendment's racial preoccupations.

Justice Samuel F. Miller identified the "pervading purpose" of the Civil War amendments: "The freedom of the slave race, the security and firm establishment of that freedom, and the protection of the newly made freeman and citizen from the oppressions of those who had formerly exercised unlimited dominion over him." Although this preoccupation did not mean that only blacks were covered by the amendments-the Thirteenth, for example, forbade slavery for anyone-the "main purpose" of each clause of Section I of the Fourteenth Amendment was to benefit the former slaves. Miller's interpretation of the equal-protection clause was more definite: "In the light of the history of these amendments, and the pervading purpose of them ... it is not difficult to give a meaning to this clause. The existence of laws in the States where the newly emancipated negroes resided, which discriminated with gross injustice and hardship against them as a class, was the evil to be remedied by this clause." Then, in what is surely one of the worst prophecies in Supreme Court history, Miller declared, "We doubt very much whether any action of a State not directed by way of discrimination against the negroes as a class, or on account of their race, will ever be held to come within the purview of this provision." 7 The Court's first pronouncement on this clause has a familiar ring to those versed in the equal-protection litigation of the last thirty years. The themes of unjust discrimination, of classification, and of special hostility to discriminations directed against one particular racial minority appear.

\section{Breaking the Promise}

Although the Court soon rethought its position about the scope of equal protection, the themes of Slaughter-House continued to direct its thinking on race. The next two major cases, Strauder v. West Virginia and Ex parte Virginia, arrived in $1880 .{ }^{8}$ Both decisions struck

${ }^{6} 16$ Wall. 36 (1873); 16 Wall. I 30.

${ }^{7}$ I 6 Wall. 36, 7I-73, 81. Emphasis supplied.

${ }^{8}$ I00 U.S. 303; 100 U.S. 339. 


\section{Equality under the Constitution}

down laws that excluded blacks from jury service, although it will be remembered that Congress had refused to pass legislation to that effect. In Strauder, Justice William Strong elaborated on the meaning of the Fourteenth Amendment:

What is this but declaring that the law in the States shall be the same for the black as for the white; that all persons, whether colored or white, shall stand equal before the laws of the States; and, in regard to the colored race, for whose protection the amendment was primarily designed, that no discrimination shall be made against them by law because of their color?

... The very fact that colored people are singled out and expressly denied by a statute all right to participate in the administration of the law, as jurors, because of their color ... is practically a brand upon them, affixed by the law, an assertion of their inferiority, and a stimulant to that race prejudice which is an impediment to securing to individuals of the race that equal justice which the law aims to secure to all others. ${ }^{9}$

This opinion echoes-not, so far as we know, intentionally-statements made by Howard, Trumbull, and Stevens during the debates, as well as Senator Wilson's remarks about stigmatization. On examination, it intrigues because of the distinctions it makes. The law must be the same for blacks and whites; both races must be equal before the law; and there must be no discrimination against blacks because of their color. The first two clauses of that sentence might seem to make the third a tautology - for both races to stand equal might demand no discrimination against either-but apparently the Court did not see the matter in that light. The opinion does go on to speak not only of discrimination against blacks in particular, but of race discrimination in general. If a future black majority excluded whites from jury service, or if all Celtic Irishmen were excluded, this discrimination, too, would be unconstitutional. ${ }^{10}$ Thus the equal-protection clause forbids special restrictions of a subordinate group by a dominant one, but it is not clear whether it forbids all racial discrimination. Hindsight should not make too much of distinctions that may be more important to us now than they were to the Supreme Court one hundred years ago. But it is interesting to note that briefs in reverse discrimination cases in the I970s cite Strauder as authority against such programs-cutting off the first sentence I quoted at the second semicolon. ${ }^{11}$

${ }^{9}$ 100 U.S. $303,307-8$.

${ }^{10}$ Ibid., p. 308.

${ }^{11}$ See Ann Fagan Ginger, ed., De Funis $v$. Odegaard and the University of Washington: The University Admissions Case (Dobbs Ferry, N.Y.: Oceana, 1975), "Petitioners' Opening Brief," I:323. 
Six years after Strauder, the Court invalidated a law that, as applied, discriminated against Orientals. Yick Wo v. Hopkins declared that the due-process and equal-protection clauses "are universal in their application, to all persons within the territorial jurisdiction, without regard to any differences of race, of color, or of nationality." ${ }^{12}$ Slaughter-House, Strauder, and Yick Wo settled this much: whatever else the Fourteenth Amendment did or did not do, it forbade invidious discrimination on the basis of race. This remains good law. But two cases decided in 1883 had limited this doctrine. The Civil Rights Cases restricted the scope of the amendment to discriminations imposed by state authority. ${ }^{13}$ The Court insisted that the amendment did not reach the acts of private individuals, and invalidated two sections of the I 875 law. This principle, too, remains dogma, although the courts now have a somewhat broader notion of what constitutes "state action."

Pace v. Alabama dealt with a racial discrimination that did not single out one particular group. At issue was a law forbidding marriage or sexual intercourse beteen whites and Negroes. The Court found no violation of the equal-protection clause. Justice Stephen J. Field insisted that this law was no more discriminatory than Alabama's general prohibition of fornication and adultery:

The two sections of the code are entirely consistent. The one prescribes generally a punishment for an offence committed between persons of different sexes; the other prescribes a punishment for an offence which can only be committed where the two sexes are of different races. There is in neither section any discrimination against either race. Section 4 I 84 equally includes the offence when the persons of the two sexes are both white and when they are both black. Section 4 I 89 applies the same punishment to both offenders, the white and the black.... The punishment of each offending person, white or black, is the same. ${ }^{14}$

That, of course, was what Trumbull and Fessenden had said. Antimiscegenation laws were compatible with the equal-protection clause as long as they applied to both races. The Fourteenth Amendment prevented the states from treating one race as inferior to the other, but it allowed the states to separate the races from each other. It was an easy step from Pace to Plessy. There, thirteen years later, the Court upheld de jure segregation in railroad cars. Justice Henry Brown wrote: "A statute which implies merely a legal distinction between the white

\footnotetext{
${ }^{12}$ I I 8 U.S. 356,369 (1886).

${ }^{13}$ I09 U.S. 3 (I 883).

${ }^{14}$ I06 U.S. 583,585 .
} 


\section{Equality under the Constitution}

and colored races ... has no tendency to destroy the legal equality of the two races." Brown went on to elaborate, if not expatiate on, this point:

The object of the amendment was undoubtedly to enforce the absolute equality of the two races before the law, but in the nature of things it could not have been intended to abolish distinctions based upon color, or to enforce social, as distinguished from political equality, or a commingling of the two races upon terms unsatisfactory to either. Laws permitting, and even requiring, their separation in places where they are liable to be brought into contact do not necessarily imply the inferiority of either race to the other, and have been generally, if not universally, recognized as within the competency of the state legislatures.

Brown then addressed himself to Plessy's failure to recognize this distinction:

We consider the underlying fallacy of the plaintiff's argument to consist in the assumption that the enforced separation of the two races stamps the colored race with a badge of inferiority. If this be so, it is not by reason of anything found in the act, but solely because the colored race chooses to put that construction upon it.... The argument also assumes that social prejudices may be overcome by legislation.... We cannot accept this proposition. If the two races are to meet upon terms of social equality, it must be as the result of natural affinities.... ${ }^{\text {is }}$

Again, as in Pace, separate may be equal; both races are treated the same. It is the exposition of this argument that later got the Court into trouble. The two races are equal, but only because of the law and only before the law. This equality depends exclusively on a constitutional amendment. Furthermore, the equality that the law can establish is an artificial construct, and its scope is limited.

Legal or political equality is distinguished here from social equality, just as it was in the debates on Sumner's civil rights bill. The meaning of that term is no clearer for the Court than it was for Congress. Does "social equality" mean that the races are intrinsically equal, identical, or equivalent in worth, or does it mean that each race thinks the other is its equal? Whatever the concept means, it differs from legal equality in at least two ways. First, apparently only social equals flock together. For members of different races to share a railroad car is an indication of social equality, but for both races to share the jury box is an indication of legal equality. Second, social equality cannot be established by legislation.

$$
{ }^{15}{ }_{1} 63 \text { U.S. } 537,543,544,551-52 .
$$


Plessy has been labeled "a compound of bad logic, bad history, bad sociology, and bad constitutional law." ${ }^{16}$ Besides, the opinion contradicts itself. It denies that de jure segregation implies inferiority, but insists that integration would imply equality. (Every year the students in my civil liberties class take great pleasure in pointing out this contradiction.) Upholding Louisiana's power to classify Plessy, seven-eighths white, as Negro, the opinion includes this passage:

It is claimed by the plaintiff in error that, in any mixed community, the reputation of belonging to the dominant race, in this case the white race, is property, in the same sense that right of action, or of inheritance, is property. ... We are unable to see how this statute deprives him of, or in any way affects his right to, such property. If he be a white man and assigned to a colored coach, he may have his action for damages against the company for being deprived of his so-called property. Upon the other hand, if he be a colored man and be so assigned, he has been deprived of no property, since he is not lawfully entitled to the reputation of being a white man. ${ }^{17}$

So the races are equal before the law, but a white person may sue if mislabeled. The absurdity of the "separate but equal" rule is shown by the way its defense becomes mired in contradictions. Justice John Marshall Harlan, in his famous dissent, and a unanimous Court, in Brown v. Board of Education, make plain what by now needs no further explanation: that segregation imposed on a subject race by a dominant one does indeed constitute inferior treatment. ${ }^{18}$

Plessy v. Ferguson is an anachronism now, but one that is crucial for our understanding of constitutional equality. It has the same incredulous tone that pervades the privileges-and-immunities portions of Slaughter-House; surely the authors of the Fourteenth Amendment could not have intended to change the world quite this much. The Court did not entertain the possibility that drastic fundamental change was just what the authors had intended. Most criticisms of Plessy have emphasized its dubious distinction between legal and social equality. But it made another distinction, which has continued to influence our thinking: between discrimination against a particular race, to which the Fourteenth Amendment applied, and discrimination imposed evenhandedly on all races, which the amendment did not reach. This distinction could not bear critical analysis, but it prevailed as law,

${ }^{16}$ Harris, Quest for Equality, p. IоI.

${ }^{17}$ I6 63 U.S. 537, 549.

${ }^{18}$ Indeed, it is likely that any form of segregation implies inferiority. I am indebted to a student in my 1979 civil liberties class for pointing this out; he used as an illustration the separation of the sexes in Orthodox Jewish synagogues. 
though increasingly shaky law, until $1954 \cdot{ }^{19}$ And because it prevailed, the United States remained a society of racism under law, almost as if the Civil War amendments had never been passed.

\section{The Roots of Suspect Classification}

Nearly fifty years elapsed before the Court again found it necessary to theorize about racial equality. When it did, it helped to bring about the destruction of its old doctrine. The new rule came from a peculiar source, two decisions that, first, had nothing to do with the Fourteenth Amendment, and second, were as racist and repressive as Pace and Plessy: the first two Japanese relocation cases, Hirabayashi v. United States and Korematsu v. United States.

In Hirabayashi, Chief Justice Harlan Stone stressed the fact that the Constitution contains no equal-protection guarantee binding on the national government. ${ }^{20}$ This interpretation was a correct literal reading, but the situation seems to have called for some structural analysis. The Court was considering an executive order that restricted individual rights on the basis of race. What better place in the Constitution could the judges have looked to for guidance than the Civil War amendments? Ignoring these provisions was too easy a way out in the Japanese cases. And it is disturbing that doctrines developed in cases that disavowed any equal-protection underpinnings would later be used to interpret the equal-protection clause. Such extrapolation could only weaken the guarantee.

In Korematsu, Justice Black announced a rule that he then failed to apply. "It should be noted, to begin with, that all legal restrictions which curtail the civil rights of a single racial group are immediately suspect. That is not to say that all such restrictions are unconstitutional. It is to say that courts must subject them to the most rigid scrutiny." Black appeared to regard this principle as axiomatic. He did not cite a single precedent to support it. ${ }^{21}$ Lack of precedent hardly

\footnotetext{
${ }^{19}$ See Missouri ex rel. Gaines v. Canada, 305 U.S. 337 (1938); Sipuel v. Board of Regents, 332 U.S. 63 I (1948); Sweatt v. Painter, 334 U.S. 629 (I950); McLaurin v. Oklahoma State Regents, 334 U.S. 637 (1950).

${ }^{20} 320$ U.S. 81, 100 (1943).

${ }^{21} 323$ U.S. 2 I 4, 2 I 6 (I 944). Justice Black might have cited Skinner v. Oklahoma, at least as dictum. There Justice William O. Douglas wrote for the Court, "When the law lays an unequal hand on those who have committed intrinsically the same quality of offense and sterilizes one and not the other, it has made as invidious a discrimination as if it had selected a particular race or nationality for oppressive treatment" (31 6 U.S. 535, 54I [1942]; emphasis supplied). Perhaps, though, Black preferred not to cite this case, since Skinner invalidated the law at issue while Korematsu upheld the executive order.
} 
mattered in Korematsu, since Executive Order 9066 was upheld. But Korematsu provided the base on which later equal-protection litigation has built. Those three sentences, which may have been intended only as dicta to sweeten a bitter pill, have been cited as precedent in subsequent landmark Fourteenth Amendment cases, which in their turn have become binding precedents. Ironically, it is this racist decision that introduced the suspect-classification rule.

But maybe not ironically. For the protection given to racial groups not only was absent from Korematsu, but is qualified in general. The rule does not forbid all discrimination directed against a racial group. It leaves a loophole for those discriminations that are judged necessary. Thus it has nowhere near the import of Harlan's dissent in Plessy: "I deny that any legislative body may have regard to the race of citizens when the civil rights of those citizens are involved." 22 Still, "rigid scrutiny" is a tougher standard than the old rational-basis test, and it would have dictated Harlan's preferred result. And Korematsu, on paper at least, does state that the Constitution protects the civil rights of all races, not just blacks.

As dogma, Korematsu is suspended in constitutional space; it is supported by no specific parts of the Constitution. But later decisions grafted Black's opening sentence onto the equal-protection clause, and some of those cases found arguments to support it. They also extended the Korematsu ruling in three significant respects. The rule announced there was limited, first, to racial discriminations; second, to discriminations against a racial group (thus following Strauder, Yick Wo, and Plessy); and third, to discriminations that curtailed the civil rights of a racial group. But subsequent cases negate the distinction between invidious and neutral discriminations, blur the distinction between civil rights and less vital interests, and give "suspect classification" a meaning that goes well beyond race discrimination. Still more important, these decisions have in effect put suspect classification and strict scrutiny into the Constitution itself. ${ }^{23}$

\section{The End of Separate but Equal}

The Court's famous opinion in the first Brown v. Board of Education case, whose elegant phrases hardly need repetition, owes no ob-

${ }^{22}$ I63 U.S. 537, 554-55 (1896).

${ }^{23}$ See Walter F. Murphy, "Civil Liberties and the Japanese American Cases: A Study in the Uses of Stare Decisis," Western Political Quarterly I I (March I 958):3-1 3 . 
vious debt to Korematsu. Its emphasis was not on the suspectness of race discrimination but on the effects of a particular example of it, de jure school desegregation, on a particular group, black children. But some of the briefs in Brown and its companions did rely on the Japanese relocation cases to argue that all racial discrimination was odious and suspect. ${ }^{24}$ Bolling v. Sharpe, the District of Columbia case that effectively incorporated the Fourteenth Amendment in the Bill of Rights before the reverse process had taken hold, announced, "Classifications based solely upon race must be scrutinized with particular care, since they are contrary to our traditions and thus constitutionally suspect." ${ }^{25}$ For the first time, the court ruled that equal protection applied to the federal government.

Chapters 2 and 3 called into question the notion that racial classification is contrary to American traditions, but presumably Chief Justice Earl Warren was referring to traditions dating from 1863 . The crucial point here, however, is that Brown and Bolling, two cases often read as one, in fact make two different arguments. In Brown, separate schools are "inherently unequal" because a racial classification that on its face applies equally to any group affected by it is in fact inseparable from the social context that produced it and reinforces the assumed inferiority of the subject group. ${ }^{26}$ This ruling takes the Strauder argument a step further: segregation, like jury exclusion, is a badge of inferiority. Bolling echoes both Korematsu and Harlan's declaration that "our Constitution is color-blind, and neither knows nor tolerates classes among citizens." ${ }^{27}$ This argument insists that something about race-it is not clear what-makes it so invidious a basis for distinguishing among people that it may be used only in extraordinary circumstances.

In these decisions, of course, each argument dictated the same results, but each arrived at those results by different means. The Brown argument is actually more subtle and complex than that of Bolling; it requires careful thought about just how a facially neutral discrimination can harm one particular group, and how we know that one race is dominant and another subject. Bolling provides an easier way to invalidate segregation; all one needs to do is to apply the general rule

${ }^{24} 347$ U.S. 483 (1954). See Philip B. Kurland and Gerhard Casper, eds., Brown $v$. Board of Education, vol. 49 of Landmark Briefs and Arguments of the Supreme Court of the United States (Arlington, Va.: University Publications of America, 1975), "Brief for Appellants, 1952 Term," pp. 32-34; "Brief for American Veterans Committee, Amicus Curiae." pp. 248-49, 256. See also Kluger, Simple Justice, p. 2 I.

${ }^{25} 347$ U.S. 497, 499 (1954).

${ }^{26} 347$ U.S. 483,495 .

${ }^{27}$ I 63 U.S. 537,559 (1896). 
that all racial discrimination is suspect to any specific instance of racial classification. The problem is that this argument not only gets to the same destination, but goes much further. The Brown argument applies only to racial discrimination that is linked to inferior treatment, while the Bolling argument rejects any racial discrimination, whatever its purpose or effect.

As each argument was fatal to Plessy v. Ferguson, each would have disposed of Pace v. Alabama. But antimiscegenation laws survived de jure segregation by ten years. ${ }^{28}$ In 1964, McLaughlin v. Florida struck down a law forbidding interracial cohabitation..$^{29}$ After that, the result three years later in Loving v. Virginia, involving a law against intermarriage, was a foregone conclusion. Certainly these laws were premised on the assumed inferiority of blacks as much as segregation was. But the Court did not stress this point. Instead, it echoed Korematsu and Bolling to conclude, in 1967, that "At the very least, the Equal Protection Clause demands that racial classifications ... . be subject to the 'most rigid scrutiny' and, if they are ever to be upheld, they must be shown to be necessary to the accomplishment of some permissible state objective, independent of the racial discrimination which it was the object of the Fourteenth Amendment to eliminate." ${ }^{30}$

But was that the object of the Fourteenth Amendment? In 1953 Brown had confronted the Court with a problem that worried it enough to call for rebriefing and reargument. De jure school segregation had existed when the amendment was passed, and, as Chapter 4 showed, the legislative history suggests no intention to change the practice. ${ }^{31}$ Although asking two opposing parties to a suit to do historical research may seem to be a dubious approach to scholarship, the Brown Court dealt with this problem in a legitimate way. It decided that the inherent difficulties in determining legislative intent, the conflicting arguments in the debates, and the changes in public education since the I 860 s rendered the history "at best . . . inconclusive." 32

The historical problem in the intermarriage cases was more serious. Chapter 4 showed that, more than once, members of Congress denied any intention to legalize intermarriage, and for just the reasons given in Pace: such laws had an equal impact on both races. But in $\mathrm{Mc}$ Laughlin, the Court, speaking through Justice Byron White, referred to "the historical fact that the central purpose of the Fourteenth

\footnotetext{
${ }^{28}$ The Court did deny review in Naim v. Naim, 350 U.S. 891, 985 (1954).

${ }^{29} 379$ U.S. 184.

${ }^{30}$ Loving v. Virginia, 388 U.S. I, I I. Emphasis supplied.

${ }^{31}$ See also Bickel, "Original Understanding."

${ }^{32} 347$ U.S. $483,489$.
} 
Amendment was to eliminate racial discrimination emanating from official sources in the States." In Loving, Warren did discuss Trumbull's statement but discounted it by quoting the "inconclusive" language from Brown. But Warren also stated that the amendment's "clear and central purpose ... was to eliminate all official state sources of invidious racial discrimination." ${ }^{33}$ The problem is that the framers did not consider this sort of discrimination "invidious."

As Chapter I pointed out, these cases represented neither the first nor the last time that the Court invalidated a practice that the framers or amenders of the Constitution had tolerated. The school prayer decisions are one example. But those rulings were legitimate because, in the light of modern reality, those specific policies violated general principles grounded in the Constitution. The problem with McLaughlin and Loving is that they laid down a general principle that the Court read into Fourteenth Amendment history, and that does not belong there. The debates not only affirm the states' power to forbid intermarriage, but they do so in words that refute the contention that the goal was to eliminate all legislation based on race. As far as intermarriage itself was concerned, the Court discussed the historical evidence and gave reasons for discounting it. But it offered no reasons-and indeed, it would be hard to find good ones-for its conclusion about the general principle. ${ }^{34}$

It took twenty-three years and six cases to establish the constitutional dogma that racial classifications, all racial classifications, are inherently suspect and sustainable only on strict scrutiny. There were serious historical problems with this doctrine. And in another ten years it would bear strange fruit, as a rule that began as an ineffective safeguard against depriving a disadvantaged group of its civil rights became an effective barrier against laws intended to remove those disadvantages. Again and again, in the reverse discrimination cases, briefs for Marco De Funis, Allan Bakke, and their amici urged on the Court the neutral import of Brown, Bolling, McLaughlin, and Loving. ${ }^{35}$ And

${ }^{33} 379$ U.S. I 84, 191-92 (1964); 388 U.S. I, 9, 10 (1967).

${ }^{34}$ This discussion is adapted from my article "Reverse Discrimination: The Dangers of Hardened Categories," Law and Policy Quarterly 4 (January 1982):7 I-94.

${ }^{35}$ On De Funis, see Ginger, ed., De Funis $v$. Odegaard: "Petitioners' Opening Brief," I:323-25; "Amicus Curiae Briefs of American Jewish Congress," I:347-48; "Advocate Society et al.," I :4 24-25; "American Jewish Rights Council," I:456; "Anti-Defamation League of B'nai Brith," I:489-9I; "Amicus Curiae Briefs of AFL-CIO," 2:523; "National Association of Manufacturers," 2:540. On Bakke, see Alfred A. Slocum, ed., Allan Bakke v. Regents of the University of California (Dobbs Ferry, N.Y.: Oceana, 1978): "Brief for Respondent in Opposition to Petition for Writ of Certiorari," 2:23 I; "Brief for Respondent," 5:51-54; “Amicus Curiae Briefs of Queens Jewish Community 
in Bakke, a majority of the California Supreme Court and at least one justice of the United States Supreme Court accepted this argument as good law. "Racial and ethnic distinctions of any sort are inherently suspect and thus call for the most exacting judicial examination." 36

But if Loving and McLaughlin had been written more nearly like Brown-if they had emphasized the link between antimiscegenation laws and racism, and shown that these laws did indeed brand blacks as inferiors-it would have been hard for any judge to write as Lewis Powell did in Bakke. If the Court had overturned these laws not because they were instances of racial discrimination but because they stigmatized blacks, just as segregation did, the cases would not have been very persuasive precedents against reverse discrimination. That fact by itself, of course, does not make the Court's choice of emphasis wrong. It does, however, reveal why the difference between the Brown and Bolling arguments is important, and it does invite speculation about why that particular choice was made.

It is impossible to know just why the justices chose as they did, since nothing in the record of either McLaughlin or Loving indicates that they realized they were making a choice. But there are several reasons why the suspect classification rule is attractive as a means of disposing of these cases. First, it is a neutral principle; it does not single out anyone, or any race, for special treatment. Thus it appears to provide equal treatment for all. Second, the notion that there is something wrong with race as a way of classifying people has a certain immediate appeal. The Court did not go into this matter in the segregation and marriage cases, but it has done so since, in rulings I shall be examining. To discriminate because of race is to discriminate because of a characteristic a person did not choose and cannot change; because of something one is, not something one did; and because of something unrelated-or at least not related in any predictable or measurable way-to any individual merit or ability. Such discrimination does indeed seem contrary to at least some American traditions, as Warren wrote in Bolling. Of course, that idea is not really what the framers

Council et al.," 5:78-79; "American Federation of Teachers," 5:136; "Order Sons of Italy" [sic], 5:I 80-82; "Young Americans for Freedom," 5:2 I I-I 4; "Anti-Defamation League," 5:2 55-58; "Pacific Legal Foundation," 5:273-77; “American Jewish Committee et al.," 5:334-37; "Fraternal Order of Police et al.," 5:4 IO-I I; "U.S. Chamber of Commerce," 5:498-504. Ironically, and interestingly, the AFT, the American Jewish Congress, and the CIO (before its merger with the AFL) had all filed amicus briefs in Brown in support of the plaintiffs. The ADL had joined a similar brief prepared by the American Civil Liberties Union. See Kurland and Casper, eds., Brown v. Board of Education, passim.

${ }^{36} 438$ U.S. 265 , 29I (1978) (Powell). Emphasis supplied. See also Bakke v. Regents of the University of California, 553 P. 2 d I 52 (1976). 


\section{Equality under the Constitution}

of the Fourteenth Amendment, except possibly Sumner, were concerned about, but it does have the ring of good sense.

The third and I think the paramount reason for preferring the "suspect classification" argument to the "inherently unequal" one is that, as I have suggested, the former is simpler and easier. This is especially true in the miscegenation cases. In Brown, after all, the Court had been deluged with evidence of the adverse psychological effects of segregation on black children. In its much-criticized reliance on these studies, it was only doing what it had repeatedly been urged to do. In McLaughlin and Loving, the link between law and racism was far weaker. Forbidding people to bed or to marry one another solely on the basis of race is unlikely to generate feelings of inferiority as powerfully as separate schooling begun at age five. Certainly there were no "doll studies" to this effect-and at any rate, by 1964 the Court had learned just what even its admirers thought of that kind of evidence. Declaring that all racial discrimination was suspect eliminated any need to show that antimiscegenation laws were premised on racial inequality and thus provided an easier way to the conclusion that was reached.

I argue in Chapter 6 that what seemed difficult was nevertheless possible. Such an argument could have been made, and it would have been more faithful to the spirit of the Fourteenth Amendment. But by I 967 the doctrine that "race is a suspect classification" was well established. So was the principle that the Fourteenth Amendment applied to discrimination that was not racial at all. It was not surprising, therefore, that the suspect-classification rule appeared in nonracial cases. The Court was then forced to determine what classifications were suspect and which were not. In so doing, it developed criteria for judgment; unfortunately, the criteria were diffuse and contradictory.

\section{Suspect Classification beyond Race}

The Warren Court developed what has been called a "two-tier" theory of equal protection. The Burger Court has added an intermediate level and changed the rules somewhat, but has not abandoned the approach. Now, as has been true since the 1950s, equal-protection litigation emphasizes the type of classification involved and the importance of the interest threatened. Classifications that are unobjectionable and interests that are not fundamental belong on the bottom tier, where the Warren Court gave them minimal scrutiny and the Burger Court applies a tougher, but not hostile, standard of review called "ration- 
ality scrutiny";37 some reasonable relationship must be shown between the statute and a legitimate governmental purpose. Classifications by sex occupy the middle tier, so far by themselves: they "must serve important governmental objectives and must be substantially related to achievement of these objectives." On the highest tier, the rules get really tough; laws require "strict scrutiny" and must be "necessary ... to the accomplishment of [the state's] purpose or to the safeguarding of its interest." On this tier belong laws that threaten fundamental rights and classifications that are inherently suspect. ${ }^{38}$

My concern, for now, is with the "classification" component. However, the cases show that, whatever most of the justices think, the classification involved and the interest threatened cannot be dealt with in isolation from each other. We know already that race is one of the suspect classifications. Beyond that principle is confusion. The cases do not clarify the meaning of the term. They have told us that some classifications are suspect and some are not; what they do not do is tell us why. Or, rather, they offer two alternative explanations that compound the confusion.

Two sitting Supreme Court justices, in two landmark cases of the I970s, tried to order the decisions into a general theory of suspect classification. In Frontiero v. Richardson, Justice William J. Brennan argued, unsuccessfully, in favor of assigning sex to the category of suspect classifications. He compared sex to other classes the Court had ruled suspect: race, citing Brown, and alienage, citing Graham v. Richardson, a case I shall discuss later. Why was sex like these classifications and unlike others? Because, wrote Brennan, "it is an immutable characteristic determined solely by the accident of birth.... What differentiates sex from such nonsuspect statuses as intelligence and physical disability, and aligns it to the recognized suspect criteria, is that it frequently bears no relation to ability to perform or contribute to society." 39

This reasoning sounds sensible, but it demands some reflection. The emphasis on ability does not echo the congressional debates of 1866 , or Bingham's speech of February 1859, or the Declaration. It sounds more like Calhoun's statement that liberty "is a reward to be earned ... reserved for the intelligent, the patriotic, the virtuous, and the deserving"-reserved, at least, for those who meet the standard set by white males. Equal liberty is not a right granted by virtue of one's

${ }^{37}$ See Gunther, "In Search of Evolving Doctrine," p. 20.

${ }^{38}$ Craig v. Boren, 429 U.S. I 90 , 197 (1976); Regents v. Bakke, 438 U.S. 265, 305 (Powell). See San Antonio Independent School District v. Rodriguez, 4 I I U.S. I (I 973 ). ${ }^{39} 4$ I I U.S. 677, 686 (1973). 


\section{Equality under the Constitution}

humanity, but one contingent on ability to perform or contribute. This notion is more in tune with proslavery thought than with the thought that shaped the Fourteenth Amendment. It conforms not to the theory but to the antitheory.

There are practical as well as theoretical difficulties with the Frontiero formulation. Nothing like that passage appears in the cases Brennan cites, and in fact, one of them says something quite different. In overturning an Arizona law denying welfare benefits to aliens, Graham v. Richardson said, "Aliens as a class are a prime example of a 'discrete and insular' minority for whom such heightened judicial solicitude is appropriate." ${ }^{40}$

"Discrete and insular minority": a concept very different from those stressed in Frontiero, and not mentioned there. The phrase has as strange a history as "suspect classification" does. It comes from Justice (later Chief Justice) Stone's famous footnote in United States v. Carolene Products, where he included prejudice against such groups among the special conditions that might call for "a more searching judicial inquiry" than usual. ${ }^{41}$ This case had no more to do with the Fourteenth Amendment than Korematsu did, but it is echoed in the other major interpretive exercise of 1973, Justice Powell's opinion for the Court in San Antonio v. Rodriguez. Sustaining Texas' school-financing system, Powell declared that the "large, diverse and amorphous" class of people living in poorer school districts who were disadvantaged by the law lacked "the traditional indicia of suspectness-the class is not saddled with such disabilities, or subjected to such a history of purposeful unequal treatment, or relegated to such a position of political powerlessness, as to command extraordinary protection from the majoritarian political process." 42

The Rodriguez majority opinion and the Frontiero plurality opinion thus contain two very different formulations of the suspect-classification doctrine. And they contradict each other. Both versions cannot be correct, since they do not both describe all classifications listed as suspect. Alienage is a status that can be changed, so it does not satisfy the Frontiero test, but it is labeled suspect in Graham because, rightly or wrongly, aliens were considered a disadvantaged minority. Arguably the handicapped do constitute such a minority, but the desperate efforts mentioned in Chapter $I$ to fit them into the Frontiero rule are doomed. It is no wonder that even the Court is confused about what the "indicia of suspectness" are, since its own opinions establish con-

\footnotetext{
${ }^{40} 403$ U.S. 365,372 (1971).

${ }^{41} 304$ U.S. I 44, I 52-53, n. 4 (1938).

${ }^{42} 4$ I I U.S. I, 28.
} 


\section{From Equal Protection to Suspect Classification}

tradictory criteria. And it is not surprising that they have done so, since "suspect classification" is an idea without roots in the Constitution or its history, or even in a decision that really had to deal with its implications, and therefore can be read to mean anything or nothing.

\section{The Exclusion of Women}

The major premise of Brennan's opinion in Frontiero was a general theory of suspect classification. Its minor premise, of course, was that a specific kind of classification, sex, should be among those ranked as suspect. Since only three other justices agreed with Brennan, that premise failed to become law. But the facts that the Court struck down the particular discrimination challenged in Frontiero and that suspect classification was even mentioned themselves marked a significant change.

Traditionally, sex classifications got minimal scrutiny and were virtually always upheld. Muller v. Oregon, which I quoted in Chapter I, declared that "woman ... is properly placed in a class by herself," 43 and so matters stood until I97I. Within five years that situation changed, partly, one assumes, in response to the feminist movement and partly because of the new, tougher lower-tier scrutiny described by Gerald Gunther. ${ }^{44}$ And though the Court has not gone so far as to declare sex a suspect classification, it did create a special rule for such cases.

Reed v. Reed began the process. At issue here was an Idaho law that gave an automatic preference to men over equally qualified women in the appointment of estate administrators. The Court's unanimous opinion announced that "to give a mandatory preference to members of either sex over members of the other, merely to accomplish the elimination of hearings on the merits, is to make the very kind of arbitrary legislative choice forbidden by the Equal Protection Clause." 45 Sex still belongs on the lower tier, but this law is so silly that it fails to survive scrutiny.

Frontiero, two years later, ended the unanimity and revealed divisions on this issue which still exist within the Court. Although eight justices agreed that male and female military personnel were entitled

${ }^{43} 208$ U.S. 4 I 2,423 (1908).

44 "In Search of Evolving Doctrine." I have examined this development in "Sexual Equality and the Burger Court," Western Political Quarterly 3 I (December 1978):4709 I.

${ }^{45} 404$ U.S. 71,76 (1971). 


\section{Equality under the Constitution}

to equal dependency benefits, the majority could not agree on a test for sex discrimination. Brennan, Douglas, White, and Thurgood Marshall argued for suspect classification and strict scrutiny. Potter Stewart, in an opinion one sentence long, cited Reed. Powell, joined by Burger and Harry Blackmun, refused to call sex a suspect classification because he thought that to do so would effectively enact the Equal Rights Amendment and thus preempt a decision then before the state legislatures. William Rehnquist, the only dissenter, did not view the classification as one based solely on sex. Thus no one directly challenged Brennan's minor premise.

How valid was that argument? Sex is a suspect classification, said Brennan, for two reasons. First, it is an immutable characteristic, and second, it has little relationship to ability. These conclusions are incontrovertible, but all they prove is that sex fits Brennan's theory. They do not prove that this theory is the better of the two; worse, they do not prove that suspect classification in any form is good doctrine. So the opinion begs not one but two important questions.

Parts of the Brennan opinion indicate some awareness of the alternative theory of Rodriguez. This approach demands a change in focus from the classification to the group injured by it; in other words, from sex to women. Brennan implies that this class does indeed have some of those "traditional indicia of suspectness." He mentions the "long and unfortunate history of sex discrimination" whereby "our statute books gradually became laden with gross, stereotyped distinctions between the sexes, and, indeed, throughout much of the nineteenth century the position of women in our society was, in many respects, comparable to that of the blacks under the pre-Civil War slave codes." Even well into this century, "it can hardly be doubted that ... women still face pervasive, although at times more subtle, discrimination." ${ }^{46}$

The comparison between blacks and women has been known to arouse opposition. In Bakke, it was attacked by Justice Powell. He rejected the comparison, and since he is the author of the Rodriguez test, his views need attention. "The perception of racial classifications as inherently odious," Powell wrote, "stems from a lengthy and tragic history that gender-based classifications do not share." ${ }^{47}$ In the context of Bakke this statement is bewildering, since it appears to dictate the conclusion that for a university to reserve a number of places in medical school for women, who now comprise about half the medical student population in this country, is acceptable when such provision for blacks is not. In general, the argument itself is plain wrong.

${ }^{46} 4$ I I U.S. $677,684-86$ (1973).

${ }^{47} 438$ U.S. 265,303 (1978). 
The merest acquaintance with the relevant history reveals that sexbased classifications have been used to consign women to inferior status. Several popular books on the subject, any of which has ample supportive evidence for that statement, have appeared in the last fifteen years. ${ }^{48}$ It is true that sex discrimination has not always been recognized as invidious; indeed, it is hard to think of any traditional sex discrimination that has not at some time been defended as beneficial to women. But we need only reexamine these policies and these defenses to see how misguided they are and how oppressive they have been.

The varieties of sex discrimination are too numerous to list, let alone discuss, here. But it is easy to think of many policies that, applied to any adults other than women, are quickly recognizable as invidious. Denial of the vote, restrictions on jury service, and limitations of work opportunities come to mind. There is little, if any, evidence that these restrictions have ever been benefits.

If such policies are odious when imposed on men, how could they be acceptable for women? The writers of the old landmark decisions would probably have agreed with Powell's view that tragedy and odium are absent. The old cases seem to reflect not a belief in female inferiority, but a magnanimous recognition of special needs. The opinions are filled with such phrases as these: our old friend "woman's physical structure and the performance of maternal functions," "men must provide the first line of defense while women keep the home fires burning," and "woman is still regarded as the center of home and family life." ${ }^{49}$ That last phrase is a quotation from a 196I decision upholding restrictions on women's jury eligibility. The reader should compare it with Strauder.

By now, quoting these rationales is, or at least should be, enough to show that, far from being benign, these laws are part of a pattern of oppression. Ideas about female traits are generalizations as imperfect, and stereotypes as oppressive, as old notions about blacks. And whatever lawmakers thought they were doing, legislation on the basis of woman's traditional role in the family amounts to a role assignment by the dominant members of society for their own convenience, and that sounds suspiciously like slavery. ${ }^{50}$ If slavery for blacks was odious,

\footnotetext{
${ }^{48}$ Just two examples are Karen De Crow, Sexist Justice (New York: Random House, 1974), and Leo Kanowitz, Women and the Law: The Unfinished Revolution (Albuquerque: University of New Mexico Press, 1969).

${ }^{49}$ Muller v. Oregon, 208 U.S. 4 I 2 , 42 I (I908); U.S. v. St. Clair, 29 I Fed. Supp. I22, 1 24-25 (S.D.N.Y. 1968); Hoyt v. Florida, 368 U.S. 57, 64 (1961).

${ }^{50}$ See Baer, Chains of Protection, chaps. 6 and 7.
} 
so is pseudo-slavery for women. If the denial of full citizenship to Orientals and Hispanics has been tragic, so was its denial to women.

To the extent that Powell's distinction between race and sex discrimination rests on "tragedy and odium," then, it collapses. History provides far more support for Brennan's conclusion that both race and sex distinctions have "too often ... been inexcusably utilized to stereotype or stigmatize politically powerless segments of society." ${ }^{1}$ The greatest difference between sex and race discrimination has been in the rhetoric surrounding them.

Whichever theory one uses, therefore, sex discrimination, or discrimination against women, is suspect. But this discussion well illustrates the irreconcilability of the two definitions. Brennan's argument in Fronterio implies that, since women have been subject to disabilities, sex must be a suspect classification-whether a particular law injures women or benefits them. And that conclusion does not follow from that premise. ${ }^{52}$ The problem that haunts the reverse discrimination cases in Chapter 6 hits with full force here, too.

But the Court has not resolved any of these difficulties. The next important case after Frontiero, the case that has become the binding precedent, struck a compromise. In Craig v. Boren, Brennan, writing for a majority of seven, dropped suspect classification, at least for the time being. "To withstand constitutional challenge," he wrote, "... classifications by gender must serve important governmental objectives and must be substantially related to achievements of these objectives." The law at issue, an Oklahoma statute allowing women to buy 3.2 percent beer but no other alcoholic beverage at eighteen while men had to wait until twenty-one, fell because the statistical evidence that young men did more drunken driving than young women was not in itself closely enough related to the state's admittedly important goal of traffic safety. "While such a disparity is not trivial in a statistical sense, it hardly can form the basis for employment of a gender line as a classifying device. Certainly, if maleness is to serve as a proxy for drinking and driving, a correlation of $2 \%$ must be considered an unduly tenuous 'fit.'" 53

The Craig test was applied in two important $198 \mathrm{I}$ decisions. In both cases, however, the Court split badly on the results. In Michael M. v. Superior Court of Sonoma County, five justices voted to uphold a California law that provided that only males could be guilty of "statutory rape" of females, not the other way around. Both Rehnquist and

\footnotetext{
${ }^{51}$ Regents v. Bakke, 438 U.S. 265, 360 (1978).

${ }^{52}$ See Baer, "Sexual Equality," p. 478.

${ }^{53} 429$ U.S. 190, 197, 199 (1976).
} 


\section{From Equal Protection to Suspect Classification}

Blackmun felt that the law was substantially related to the important objective of discouraging teenage pregnancy, which obviously can be inflicted only by males on females. Brennan, dissenting, found "outmoded sexual stereotypes" in the law and insisted that it was too ineffective a means of discouraging teenage pregnancy to meet the "substantial relation to important objective" test. ${ }^{54}$ Clearly, whatever qualities this test has, it does not dictate consistent results.

In Rostker v. Goldberg, the Court upheld Congress' power to require men, but not women, to register for possible conscription. Justice Rehnquist's majority opinion cited both Craig and Michael M., concluding that "the exemption of women from registration is not only sufficiently but closely related to Congress' purpose in authorizing registration. The fact that Congress and the Executive have decided that women should not serve in combat fully justifies Congress in not authorizing their registration, since the purpose of registration is to develop a pool of potential combat troops." 55 The dissents, by Justices White and Marshall, disagreed primarily with Rehnquist's linkage of registration and combat. No opinion challenged the exclusion of women from combat or reached the issue of sexual equality. This decision will have great practical impact, but it is not a major contribution to doctrine.

So gender discrimination is in a class by itself, on a level between the two tiers, with its own rules. The standard is so slippery that it is hard to criticize, but it is equally hard to endorse. Certainly it has no support in the legislative history. The debates are confusing on this point, relying as they do on distinctions that do not stand up, but nowhere do they invite the inference that sexual distinctions were to be put midway between racial classifications and innocuous ones. History provides very limited support for either the conclusion that discriminations against women are as odious as those against blacks or the conclusion that they are permissible, and none for the intermediate conclusion. Still, these decisions are no more unfaithful to legislative history than Brown or Loving is. Craig v. Boren is so obviously a political compromise on a controversial issue that it is tempting just to leave it at that. At any rate, the only alternative we have so far is to rank some gender discriminations as suspect-and the objection to

\footnotetext{
${ }^{54}$ I O I S.Ct. I 200.

${ }^{55}$ IOI S.Ct. 2646, 2658. The temptation to express a personal opinion on this case is powerful. I think the case could have been dealt with nicely by what might be termed extrastructural analysis; i.e, considering both what is in the Constitution and what was not put in. In other words: No ERA, no draft.
} 


\section{Equality under the Constitution}

that conclusion is that the suspect-classification doctrine is itself unacceptable.

Gender has not been the only category excluded from the upper tier. But gender was excluded even though it fits both definitions of suspect classification. The next cases include claims that fit neither definition, and one, at least, whose result appears to depend on which particular definition the judges are using. And they suggest, if any further evidence is needed, that there is something very wrong with equalprotection doctrine.

\section{Education, Retirement, and Reverse Discrimination}

However confused the rule or rules are, judges continue to use them. Some of the cases that have ruled that certain classifications are not suspect are directly pertinent here. Rodriguez is among them. It was a messy case; Justice Powell is quite correct in his conclusion that it was hard to identify either an exact group of people who were being deprived or a specific right of which they were being deprived.

First, although his conclusion that "people living in low-yield school districts" could not be identified with "the poor," who do bear some of the "traditional indicia," was supported mainly by a study from Connecticut, not Texas, no such identification was demonstrated in Texas, either. And as Stewart pointed out, the relevant suspect classification was "actual or functional indigency, [not] comparative poverty vis-a-vis comparative affluence." Second, whether or not education can be ranked as a fundamental right-and Powell insisted it cannot be-the children were not deprived of it; they just had less money spent on their education than did children in wealthier districts. No perfect correlation existed between expenditure and quality of education. Therefore, what Justice Marshall's dissent called "the Court's rigidified approach to equal protection analysis" seemed to demand the result the Court reached. ${ }^{56}$

But the dissenting argument is powerful. Marshall pointed out that the residents of the poorest districts were in fact paying proportionately higher taxes for a cheaper education; that there was evidence that the quality of the schooling was inferior; and that those affected were, after all, children, who did not choose where they lived. Another salient fact was that the affected district's population was 90 percent Mexican-American and 6 percent black. Marshall stressed the impor-

$$
{ }^{56} 4 \text { II U.S. I, 23, 6In, 29-39, } 98 \text { (1973). }
$$


tance of education and the fact that the Court had recognized as "fundamental" other rights not specified in the Constitution. ${ }^{57}$ Taken together, those factors add up to an unequal share in an important benefit for minority children, thus militating against the legitimacy of the financing scheme.

But the rule does not permit us to take all these factors together. It demands that we weigh separately the interests involved and the classification invoked. Since the case did not fit into the categories of fundamental right and suspect classification, the law was upheld.

Marshall not only criticized this ruling, but attempted to develop an alternative doctrine for equal-protection cases. He recommended "an approach in which concentration is placed upon the character of the classification in question, the relative importance to individuals in the class discriminated against of the governmental benefits that they do not receive, and the interests in support of the classification." ${ }^{58}$ As a test, this approach has its defects, for it does not tell us how to weigh these considerations and what standards to judge them by. Nor has Marshall done so since, although he continues to use this approach. In his dissent in Harris v. McRae, the case that upheld the Hyde Amendment, restricting federal funding for abortions, he suggested that his use of this doctrine in that context was "not dissimilar" to the Craig test. ${ }^{59}$ But that observation does not help much, since it does not tell us whether that context is different from that of Rodriguez or any other, and if so, why. Marshall does not have a mature alternative rule for equal-protection cases, but this approach will provide a guideline by which to test these decisions.

The next set of cases provides more evidence of defects in the prevailing rule and the superiority of Marshall's developing doctrine. Massachusetts Board of Retirement v. Murgia upheld a law that forced uniformed state police officers to retire at fifty. Quoting from Rodriguez, the per curiam opinion handled the issue thus:

While the treatment of the aged in this Nation has not been wholly free of discrimination, such persons, unlike, say, those who have been discriminated against on the basis of race or national origin, have not experienced a "history of purposeful unequal treatment" or been subjected to unique disabilities on the basis of stereotyped characteristics not truly indicative of their abilities. The class subject to the ... statute consists of uniformed state police officers over the age of 50 . It cannot be said to

${ }^{57}$ Ibid., pp. 80-8 I, 85-87, 109, I 2, 99-103.

${ }^{58}$ Ibid., p. 99. See also Dandridge v. Williams, 397 U.S. 470, 52 I (Marshall dissenting).

${ }^{59}$ I00 S.Ct. 2671, 2709, n. 6 (1980). 


\section{Equality under the Constitution}

discriminate only against the elderly. Rather, it draws the line at a certain age in middle life. But even old age does not define a "discrete and insular" group, in need of "extraordinary protection from the majoritarian political process." Instead, it marks a stage that each of us will reach if we live out our normal life span. Even if the statute could be said to impose a penalty upon a class defined as the aged, it would not impose a distinction sufficiently akin to those classifications that we have found suspect to call for strict judicial scrutiny. ${ }^{60}$

Apparently the classification is not suspect because the class singled out is so large. The result seems to be that the larger the group restricted, the greater the chances the law will pass muster. That reasoning is dubious enough, but the opinion has an even worse flaw. If people who share a given trait do not constitute a powerless minority, I can think of no more effective way of turning them into one than by taking their jobs away. ${ }^{61} \mathrm{By}$ analogy, Jews are not a powerless minority in this country, but we would be suspicious if immigration officials started stamping "Jew" across their passports-and we should be. Laws can, after all, separate and isolate groups.

Three years after Murgia, in 1979, Vance v. Bradley sustained a federal law requiring Foreign Service employees to retire at sixty. The employees avoided both the suspect-group and the fundamental-right arguments, alleging that the law did not even satisfy the rational-basis test. The Court disagreed, citing both Murgia and Rodriguez as precedents. Its argument for the law's rationality did not limit itself to the generalizations about age and ability which had persuaded it in $1976 .{ }^{62}$ There was more:

The appellants submit that one of their legitimate and substantial goals is to recruit and train and to assure the professional competence, as well as the mental and physical reliability, of the corps of public servants who hold positions critical to our foreign relations, who more often than not serve overseas, frequently under difficult and demanding conditions, and who must be ready for such assignments at any time. ... The appellants also submit that compulsory retirement at age 60 furthers this end in two principal ways: first, as an integral part of the personnel policies of the Service designed to create predictable promotion opportunities and thus spur morale and stimulate superior performance in the ranks; secondly, by removing from the Service those who are sufficiently old that they may be less equipped or less ready than younger persons to face the

${ }^{60} 427$ U.S. $307,313-14$ (1976).

${ }^{61}$ Justice Marshall touches on this problem in his dissent (ibid., pp. 323-24).

${ }^{62} 440$ U.S. 93, 96-98, 103-5, I I I-I 2. See Massachusetts Board of Retirement v. Murgia, 427 U.S. $307,317-18$. 
rigors of overseas duty in the Foreign Service. The District Court rejected each of these latter submissions and in our view erred in each instance. ${ }^{63}$

Whose promotion? Whose morale? Not, obviously, those of the retirees, but of those whose rise will be accelerated by their seniors' retirement. That rationale comes close to an absolute preference for the interests of one group of people over those of another group. What it implies, bluntly, is that the sixty-year-olds just do not count. They do not enjoy a right to equal respect and concern. How such a ranking is compatible with constitutional equality defies understanding. But such is the result of the rigidified approach that assigns age discrimination to the lower tier.

A third group of cases that collide with the approach are those involving reverse discrimination. These cases illustrate the inconsistencies of the rule, for here it is of crucial importance which formulation of suspect classification is employed. The two alternatives dictate opposite results. Powell solved that problem in Bakke by insisting that race was a suspect classification, not because of anything that might be said about it, but because it just was; this was a given, just as Black had said in Korematsu.

Petitioner argues that the Court below erred in applying strict scrutiny to the special admissions program because white males, such as respondent, are not a "discrete and insular minority" requiring extraordinary protection from the majoritarian political process. This rationale, however, has never been invoked in our decisions as a prerequisite to subjecting racial or ethnic classifications to strict scrutiny. Nor has this Court held that discreteness and insularity constitute necessary preconditions to a holding that a particular classification is invidious. These characteristics may be relevant in deciding whether or not to add new types of classifications to the list of "suspect" categories or whether a particular classification survives close examination. Racial and ethnic classifications, however, are subject to stringent examination without regard to these additional characteristics. ${ }^{64}$

Race, then, is a suspect classification whether such a law helps or harms disadvantaged minorities. But Graham, Rodriguez, and Murgia are three of the cases Powell cites, and if they did not hold that discreteness and insularity were conditions of suspectness, they came pretty close. Between 1973 and 1978 , then, the confusion became worse.

The Court has not adopted Powell's view, but several justices do see the matter this way. The passage I just quoted suggests that Powell

${ }^{63} 440$ U.S. $93,97-98$.

${ }^{64} 438$ U.S. 265 , 290-91. 
himself did, in 1978 at least, but some concessions he made and his vote in a later case suggest that his views may be changing. Stewart and Rehnquist go even further. In a 1980 decision, Stewart quoted Harlan's "color-blind" language in Plessy and Rehnquist joined the opinion. Stevens has insisted on a unilateral strict-scrutiny standard for all race discrimination. ${ }^{65}$

Two of the three decisions on the merits the Court has made so far in this area have sustained policies of reverse discrimination, so the Court cannot be accused of rigid adherence to the old doctrine. But the fact that at least three, and possibly four, justices do try to fit the new cases into the old category may bode ill. ${ }^{66}$

\section{Conclusion}

The suspect-classification doctrine, as it now precariously exists, was an intelligible response to a particular set of issues, and provided a way out of a bind into which the Court had reasoned itself over the years. But it has no roots; it distorts history; it has disquieting echoes of antitheory; it has developed in two contradictory directions; and, applied to several contemporary issues, it permits absurd results. I have not yet found any rule with which to replace the doctrine. The next four chapters provide further tests of the prevailing doctrine, and allow us to consider alternative approaches, as I explore the issues discussed in Chapter I. Of the issues discussed, only reverse discrimination, the subject of Chapter 6, fits into the framework of traditional doctrine. Age seems to fit, too, as long as one sticks to maximum age limits, but in cases involving minors, the equal-protection doctrines do not appear, and the cases are not handled within the model. This lack of fit is even more evident when we examine cases involving disability and sexual orientation. At first glance, they may not seem to belong in this discussion at all, for they are not classified or decided as equal-protection cases. But, I shall argue, that fact in itself is indicative of still more defects in the doctrine. For these very rules hide the fact that these cases are very much concerned with equality, and by their omissions allow decisions that brand and stigmatize, relegate people to inferior status, and deprive them of any semblance of equal rights. These results confound the general principles of the Fourteenth Amendment.

\footnotetext{
${ }^{65}$ Ibid., pp. 31 9-20; Fullilove v. Klutznick, roo S.Ct. 2758, 2798-28 I 4 (1980).

${ }^{66}$ This discussion is adapted from Baer, "Reverse Discrimination."
} 